\title{
A leitora e sua relação com o jornal Estado de Minas
}

\author{
Patrícia Espírito Santo
}

\begin{abstract}
Jornalista. Mestre em Ciência da Informação pelo PPGCI/UFMG. Doutoranda em Ciência da Informação pelo PPGCI/UFMG
\end{abstract}

Lígia Maria Moreira Dumont

\begin{abstract}
Pós-doutora pela École de Hautes Études em Sciences Sociales, Paris. Professora associada e atual diretora da ECI/UFMG
\end{abstract}

Estuda a leitura e a interação feminina com o jornal Estado de Minas. Procura identificar os elementos necessários para inserir a mulher como leitora de jornais, e como ela se reporta e interage com aqueles que "constroem" e divulgam a notícia. Analisa a linguagem dos jornais e conclui que a produção da informação se dá através de um discurso masculino. Analisa ainda como a mulher se insere neste contexto e os possíveis impactos que a informação jornalística traz para o gênero feminino.

Palavras Chave: Jornalismo - Informação; Mulher Discurso; Leitura Feminina.

\section{The female reader and her relationship with the newspaper Estado de Minas}

The present paper looks into female reading and interaction in the newspaper Estado de Minas. It identifies the necessary elements to include women as newspaper readers as well as the way they report themselves and interact with those that "build up" and broadcast the news. The study talks about information production through a male language, how women are included in that context and the possible impacts of journalistic information onto the female gender.

Keywords: Journalism - Information; Women Discourse; Feminine Reading.

Recebido em 18.03.2008 Aceito em 04.12.2009 


\section{Introdução}

Situamo-nos ao lado dos teóricos que estudam as implicações da construção de linguagens e discursos que constituem a informação e a comunicação entre os agentes sociais. A informação só leva ao conhecimento se for percebida e entendida como um instrumento modificador da consciência do indivíduo e de seu grupo social. Diferentemente da informação, o conhecimento só existe quando há alguém a quem se vincular, a quem pertencer, um conhecedor.

$\mathrm{Na}$ visão de Barreto (2002), a informação sintoniza o homem com a memória de seu passado e com as perspectivas de seu futuro, enquanto o conhecimento é "uma alteração provocada no estado cognitivo do indivíduo e organizada em estruturas mentais por meio das quais o sujeito assimila o meio" (p. 49). Ou, ainda, o conhecimento é o "objetivo da informação, que permanece sendo a apreensão de sentidos ou seres em sua significação" (LE COADIC, 1996, p. 5).

Por isso, quem detém a propriedade dos estoques de informação determina sua distribuição e condiciona potencialmente a produção do conhecimento. "Os produtores de informação não podem dizer ao indivíduo o que pensar, mas podem induzir sobre o que pensar" (BARRETO, 2002, p. 49).

Para Dumont (1998), a informação causa alguma reação no sujeito se coincidir com seus anseios, seu contexto, seu repertório. Entre os objetivos que levam uma pessoa a buscar informações através da leitura, aparecem, segundo a autora, o lazer; a necessidade de atualizar os conhecimentos, de saber mais sobre determinado assunto e a posterior satisfação de "matar a curiosidade"; podendo chegar, também, ao desejo de "liberar o espírito". Ela nos lembra que processos cognitivos, como pensar, imaginar, relembrar e solucionar problemas, podem estar relacionados com o comportamento de busca de informação.

As maneiras de compreender os produtos da mídia variam entre os indivíduos, assim como entre um contexto sócio-histórico e outro. Para Thompson (1999), o "significado" de uma informação transmitida pela mídia não é um fenômeno estático, fixo e transparente para todos.

Antes, o significado ou o sentido de uma mensagem deve ser visto como um fenômeno complexo e mutável, continuamente renovado e, até certo ponto, transformado pelo próprio processo de recepção, interpretação e reinterpretação (THOMPSON, 1999, p. 44).

O autor conclui dizendo que, ao interpretar as mensagens, os indivíduos as incorporam à própria compreensão que têm de si mesmos e dos outros. Eles as usam como veículos para refletirem sobre si mesmos, os outros e o mundo ao qual pertencem.

Apropriar-se de uma mensagem é apoderar-se de um conteúdo significativo e torná-lo próprio. É assimilar a mensagem e incorporá-la à própria [...] e aos contextos e 
circunstâncias em que vivemos [...] que normalmente são bem diferentes daqueles em que a mensagem foi produzida (THOMPSON, 1999, p. 45).

As informações transmitidas pela mídia são comumente discutidas por indivíduos tanto no momento da recepção quanto posteriormente. Elas são, portanto, elaboradas discursivamente e compartilhadas num círculo amplo de indivíduos.

Dentro deste contexto, procuramos estudar a mulher enquanto uma construção social - perspectiva dos estudos de gênero -, ainda sobre os domínios do patriarcado - discriminação e dominação simbólica -; e o uso da informação enquanto veículo de manutenção, manipulação e/ou transformação da sociedade. Como a informação, enquanto fenômeno social, possui dimensões em todas as esferas, política, econômica, cultural e histórica, procuramos analisá-la levando em consideração esses contextos.

Entendemos que o acesso à informação é fator decisivo para a mudança cultural e social da mulher, e nos preocupamos com o que ela tem conseguido fazer com a informação jornalística à qual tem acesso, com vistas a alcançar maior autonomia, a modificar sua condição econômica, social e política, que, em muitos casos, ainda permanece atrelada à do homem.

Os três maiores jornais impressos brasileiros em circulação têm um grande público leitor feminino: $48 \%$ dos leitores da Folha de São Paulo, $51 \%$ de O Globo e $46 \%$ de O Estado de São Paulo. Escolhemos estudar a relação que as leitoras do Estado de Minas mantêm com a informação nele contida, por ser esse o maior jornal de referência em circulação no estado de Minas Gerais. A proporção de leitores do jornal é de $48 \%$ homens e $52 \%$ mulheres ${ }^{1}$.

Ao se depararem diariamente com as páginas do jornal, estarão as mulheres à procura do quê? Com que objetivos elas o lêem e quanto do que lêem interfere em seu crescimento pessoal e em sua participação social? Elas se "interessam" em interagir com o jornal e em intervir na construção da informação jornalística? Responder a essas questões foi o objetivo da dissertação de mestrado em Ciência da Informação, de autoria de Espírito Santo (2007), cujas conclusões se seguem.

\section{A pesquisa de campo}

Esta pesquisa surgiu a partir da nossa inquietação quanto à maneira como o gênero feminino figura na grande imprensa, e como a mulher se relaciona com os jornais impressos. Sabemos do interesse dela em lê-los para se manter bem informada, porém não percebemos, por parte dos grandes jornais, a iniciativa de tratá-la com a mesma importância com

1 Informações disponibilizadas, ao jornal Estado de Minas, pelo Instituto Ipsos Marplan, em 30 julho de 2006. Esse instituto pesquisa os hábitos de exposição aos meios - televisão, rádio, revista, jornal - em nove estados brasileiros, sendo o acesso aos dados restrito aos seus associados, entre eles Folha de São Paulo, O Globo, O Estado de São Paulo e Estado de Minas. 
que trata o gênero masculino. Também não percebemos, por parte da leitora, a intenção de participar da construção da informação através do envio de sua opinião, seja sobre a abordagem dos fatos por parte da imprensa ou sobre sua visão particular destes ou de outros acontecimentos.

Uma de nossas hipóteses era a de que a mulher, ao ler um jornal impresso, buscava, principalmente, informação, para adquirir cultura e conhecimento. Dessa forma, ela a utiliza em conversas formais, no ambiente de trabalho, e informais, em sua vida familiar e social, com o objetivo de inserir-se e de participar da sociedade como cidadã.

Inicialmente acreditávamos, também, que a leitora percebia a mulher retratada nas páginas do jornal, tanto em textos como em imagens fotográficas e gráficas, como alguém ausente das grandes decisões políticas, econômicas e sociais. No entanto, através da pesquisa observamos que a ausência da mulher nas páginas do jornal é fato talvez pouco percebido, tanto pelos leitores, de uma maneira geral, quanto pela direção da empresa e da redação. Constatamos que são poucas as contestações femininas com relação a essa realidade.

$\mathrm{Na}$ tentativa de testar nossas hipóteses, optamos por realizar uma pesquisa de campo de metodologia mista, quantitativa e qualitativa. Fizemos um levantamento quantitativo da publicação de cartas assinadas por homens e por mulheres, no período de 25 de julho a 23 de agosto de 2006, na editoria de Opinião dos jornais Estado de Minas, Hoje em Dia, O Tempo, O Estado de São Paulo, Folha de São Paulo, O Globo e Correio Brasiliense. Ao todo, estes veículos publicaram juntos 1838 cartas, sendo 1493 masculinas e 345 femininas.

Tínhamos como hipótese que, não apenas as de Minas Gerais, mas também as leitoras de outros estados influem e atuam de forma silenciosa nos grandes jornais impressos brasileiros. Acreditávamos que a cultura de desvalorização da manifestação pública do feminino é um dos fatores que desestimula a mulher a participar dos espaços dedicados à manifestação dos leitores, o que colabora para deixá-las, muitas vezes, às margens da produção da informação jornalística. Não foram contabilizadas as cartas assinadas por assessores de imprensa, tanto do sexo masculino quanto do feminino, por não expressarem a opinião da pessoa e sim da instituição que representam. Também não foram consideradas as identificadas apenas pelas iniciais do autor e as assinadas por pessoas cujos nomes não identificam o sexo.

Fizemos também o levantamento do número de cartas enviadas via fax, correios ou e-mail à editoria de Opinião do Estado de Minas, entre 25 de julho e 23 de agosto de 2006, tanto por homens quanto por mulheres. Confrontamos o número de cartas enviadas por mulheres com o total publicado. O volume total de cartas enviadas ao jornal foi de 275. Dentre elas, 59 eram de mulheres, sendo que 32 foram publicadas. Nosso objetivo era identificar se o número de colaborações femininas editadas era devido principalmente à baixa participação de mulheres ou a uma prédisposição a não publicá-las por parte dos jornalistas. 
Na tentativa de decifrar as intenções do discurso adotado pela mídia impressa brasileira, através de seus enunciados e silêncios, em relação ao jogo de poder entre os sexos, optamos por fazer a análise do discurso da primeira página do Estado de Minas e das reportagens para as quais ela remete; visto que palavras e fotografias contêm elementos que devem ser interpretados além de seus significados literais. O estudo foi feito com as capas publicadas no período de 25 de julho a 23 de agosto de 2006.

Utilizamos alguns princípios da análise do discurso da linha francesa, que estuda os efeitos das mensagens sobre o receptor e sobre a cultura na qual está inserido, e procura decifrar as intenções por trás do discurso. Como princípios, utilizamos, principalmente, a "leitura" da diagramação das páginas, do destaque dado a determinados temas em detrimento de outros, da linguagem adotada e dos pressupostos subentendidos, na tentativa de decifrar e mapear a maneira como o jornal apresenta 0 gênero feminino aos seus leitores.

A análise do discurso tem por objetivo pensar o dispositivo de enunciação - no nosso caso o Estado de Minas -, que associa uma organização textual e um lugar social determinados, vinculando o texto e o contexto no qual se dá a comunicação. "Não se interessa pela 'verdadeira' posição ideológica do enunciador real, mas pelas visões de mundo dos enunciadores inscritos no discurso" (FIORIN, 2006, p. 51).

Para conhecermos o ponto do vista da leitora sobre o jornal e a maneira como ela se relaciona com a mídia impressa, aplicamos entrevistas por telefone, no período de 01 de agosto a 28 de outubro de 2006, junto a 172 leitoras do Estado de Minas; amostra retirada do universo de assinantes do jornal, que totaliza cerca de 70 mil, segundo a Superintendência de Circulação da empresa. Pesquisas como Ipsos Marplan (2006) estimam que o número de mulheres leitoras do Estado de Minas seja de 578 mil, sendo que a grande maioria faz uma leitura compartilhada, ou seja, não é ela que compra o jornal que lê.

A técnica escolhida foi a de entrevista semi-estruturada. Através de questões fechadas, procurou-se saber quais os cadernos a mulher lê, e quais, na opinião das leitoras, destacam a participação das mulheres na sociedade. Procurou-se, também, medir a freqüência com a qual elas lêem o jornal. Já as perguntas abertas, num total de oito, deram à entrevistada a oportunidade de discorrer sobre o tema proposto, sem respostas ou condições preestabelecidas que pudessem influenciar sua opinião.

\section{Resultados}

Sabemos que os resultados da pesquisa qualitativa não devem ser considerados como conclusivos e utilizados para fazer generalizações em relação à população-alvo. Mas eles podem nos auxiliar quando buscamos informações mais profundas sobre o comportamento, sobre o que faz ou pensa determinado grupo em relação ao objeto que se deseja pesquisar. Os resultados de nossa pesquisa nos possibilitaram desenvolver uma compreensão inicial dos problemas levantados, revelando valores, crenças, sensações e atitudes do público leitor feminino de jornais. Este 
tipo de abordagem torna mais evidentes aspectos da leitura feminina que não estão tão claros nem mesmo para as próprias mulheres, muito menos para a sociedade de uma maneira geral.

\subsection{Perfil das entrevistadas}

Em relação à idade, a maioria das leitoras do Estado de Minas, $72,2 \%$, tem mais de 40 anos, sendo a faixa etária entre 40 e 49 anos a que mais concentra leitoras, com 26,2\%. Leitoras mais jovens, de 20 a 29 anos, são minoria, 7\%. Quanto ao estado civil, 55,8\% das leitoras são casadas.

Há leitoras com diferentes níveis de escolaridade, sendo que $55,8 \%$ têm curso superior completo. Isso parece refletir-se, também, no grau de ocupação. 58,1 \% trabalham, sendo que a ocupação mais citada foi a de funcionária pública, com 37,4\%. Entre as que disseram não trabalhar, $60 \%$ exerceram alguma atividade remunerada anteriormente, encontrando-se aposentadas na ocasião da entrevista.

Os resultados nos mostram que apenas $19,8 \%$ adquiriram o hábito de ler jornal há menos de dez anos, enquanto o restante se diz leitora há mais tempo. Entre as entrevistadas, 64,5\% lêem jornal todos os dias.

Ao fazermos o cruzamento entre as leitoras que não trabalham fora de casa e sua freqüência de leitura, percebe-se que as aposentadas são as que mais lêem jornal, seja diariamente ou apenas alguns dias da semana $(65,1 \%)$, seguidas pelas donas de casa, com $27 \%$. As entrevistadas que só estudam lêem menos jornal, 6,3\%, na frente apenas das desempregadas.

Comparando-se a idade com a ocupação principal, percebe-se que aquelas que apenas estudam estão entre as faixas dos 20/29 anos e 30/39 anos, e não apareceram donas de casa com idade inferior a 30 anos.

Em relação à escolaridade, percebe-se que não há correlação entre o nível de escolaridade e um tempo maior de leitura de jornais. Ao contrário, enquanto quem tem curso superior completo ou mais despertou interesse pela leitura em média há 21 anos, e quem tem curso superior incompleto o fez há 15,3 anos, quem tem segundo grau ou ensino fundamental o fez há mais tempo: uma média de 24,2 anos e 22 anos, respectivamente. Esse resultado pode ser explicado pelo fato de um número significativo de nossas entrevistadas estarem aposentadas, 41 delas, e ter mais de 50 anos, 80 delas.

Observa-se a leitura frequente, durante os sete dias da semana, para $64 \%$ das leitoras com curso superior ou mais, assim como para $28 \%$ entre as que têm segundo grau e para $22 \%$ daquelas com o ensino fundamental. Já entre as que têm curso superior incompleto, apenas $10 \%$ lêem jornal todos os dias. Quem tem apenas o ensino fundamental é quem lê jornal com menor freqüência. 
Vimos que o nível de escolaridade não é uma variável determinante para uma leitura mais freqüente, porém o mesmo não se pode dizer em relação à ocupação principal. As que trabalham são as que lêem jornal com mais freqüência, $37,9 \%$ delas diariamente. $26,6 \%$ das que não trabalham também lêem jornal todos os dias. Não podemos nos esquecer de que, entre as leitoras que não trabalham, $60 \%$ encontram-se aposentadas, ou seja, já trabalharam um dia.

\subsection{Objetivo de leitura}

Pedimos que as entrevistadas descrevessem seus objetivos ao ler o jornal, confirmando, assim, nossa hipótese inicial de que a mulher, ao ler jornal, o faz à procura de notícias que a mantenham bem informada sobre assuntos diversos, ao contrário da crença comum, que supõe estar ela mais interessada em temas "frívolos e femininos", como beleza, culinária e fofocas.

A pergunta comportava mais de uma resposta, sendo que dois objetivos concentraram a maioria das leitoras: $58 \%$ disseram que o lêem à procura de informações novas ou que reforcem as acessadas anteriormente, e $20 \%$ para se manterem atualizadas. Optamos por diferenciar esses dois objetivos baseados em seus significados literais: informar é tomar ciência, instruir-se, e atualizar pressupõe acrescentar informações a determinado conhecimento, colocando-o em dia.

Nesse ponto, é importante lembrar que a busca de informação é básica para o processo de aprendizagem e, conseqüentemente, para o entendimento do mundo e o seu conhecimento. As leitoras buscam informação também como forma de lazer, de exercitar a leitura e de atender às suas necessidades profissionais.

Em que editorias elas atendem a esses objetivos? Essa pergunta comportava um número ilimitado de respostas, pois desejávamos conhecer quais os cadernos mais lidos, independentemente das preferências das leitoras.

Entre os cadernos do Estado de Minas, a editoria de Política é lida por 107 delas, seguida de perto pela editoria Gerais, citada por 103 leitoras, e pelo caderno de Cultura, lido por 102 entrevistadas. As funcionárias públicas lideram entre as que mais lêem todas as editorias, sendo a de Cultura a mais citada por elas, 15,1\%, seguida da Política, $14,5 \%$, Nacional, 12,8\%, Gerais e Feminino \& Masculino, ambas sendo freqüentemente lidas por $11,6 \%$. Internacional, Turismo e Bem Viver foram citadas por $9,9 \%$ das funcionárias públicas.

As leitoras assalariadas com carteira assinada também demonstraram interesse por diversas editorias, desde as consideradas de abordagem preferencialmente masculina, como Política, com 11,6\%, Internacional e Nacional, ambas com 9,9\%, até as de linguagem menos "técnica", como Cultura, com 10,5\%, e Turismo, com 9,9\%.

Para todas as categorias de trabalho, o caderno Feminino \& Masculino, de abordagem preferencialmente feminina, aparece bem cotado, porém sempre abaixo da Política e Nacional, exceto no caso das 
que regularmente trabalham por conta própria. A editoria Gerais também aparece como mais lida que o Caderno Feminino \& Masculino para a maioria das entrevistadas; esse quadro só não se verifica no caso das funcionárias públicas, das que temporariamente trabalham por conta própria e das autônomas universitárias, para quem a percentagem de leitura dos dois cadernos se iguala. Não podemos nos esquecer de que o caderno Feminino \& Masculino é semanal, sendo publicado apenas aos domingos, ao contrário das outras editorias citadas, que são diárias.

Percebe-se certa heterogeneidade na escolha dos temas por parte das leitoras que trabalham: lê-se de tudo um pouco. Mas, ao mesmo tempo, há certa homogeneidade nesta leitura: lê-se praticamente as mesmas coisas. Acreditamos, com base nas idéias de Escarpit (1958 apud DUMONT, 1998), que isso provavelmente seja devido ao estilo relativamente uniforme da vida feminina. A maioria das mulheres convive com os cuidados com a casa e a família, dividindo espaço e tempo com as atividades profissionais. Daí a necessidade de informação e atualização sobre o que se passa em todos os setores do cenário político, assim como de satisfazer suas necessidades de cultura e de "assuntos de mulher".

Ao fazermos o mesmo cruzamento de dados com os das leitoras que não trabalham fora, percebemos que eles apresentam certas similaridades, porém a preferência maior de leitura recai sobre diferentes temas. Enquanto, para as trabalhadoras, as editorias Política, Nacional e Gerais estão no topo, para as que não trabalham fora as editorias Gerais $(25,6 \%)$, Feminino \& Masculino $(23,3 \%)$ e Cultura $(22,7 \%)$ são as mais lidas. A Política só aparece como uma das mais lidas entre as leitoras que não trabalham fora, no caso das que só estudam, mas divide a mesma atenção com outras editorias: Gerais, Cultura, Bem Viver e Feminino \& Masculino.

Surgem então as perguntas: O que, efetivamente, as leitoras fazem com a informação ou a atualização que encontram no jornal? A leitura do jornal interfere em suas vidas? De que forma? Ao se informar e atualizar, elas se sentem inseridas no mundo, discutindo os acontecimentos, emitindo opinião; estariam contribuindo para a construção da sociedade? Constatamos que a informação jornalística se configura para elas como um objeto de troca no mercado, de valorização pessoal tanto aos seus olhos quanto aos dos outros e, ainda, que as "guia" na tomada de decisões, como veremos a seguir.

\subsection{Interferência}

Pedimos que as entrevistadas descrevessem de que forma os assuntos lidos no jornal interferem em sua participação na sociedade. Foi grande o número de mulheres que não opinaram - $35 \%$, sendo que $5 \%$ delas, inclusive, disseram não saber o que dizer e outras duas disseram acreditar que a leitura do jornal não interfere em nada nas suas vidas.

Esse ponto nos surpreendeu, visto que muitas leitoras se disseram interessadas na leitura de editorias como Política e Gerais, com o objetivo principal de se informar; 0 que as possibilita se posicionarem 
publicamente. Passamos a nos questionar se muitas das respostas dadas ao questionário condizem realmente com a realidade.

Sabíamos que essa seria uma pergunta difícil de responder, assim como tínhamos o conhecimento de que é impossível mensurar o quanto e de que forma a informação modifica a consciência dos indivíduos e grupos. As interferências podem ocorrer em situações concretas, como mudar a rota de uma viagem ao ler no jornal sobre a queda de uma ponte, ou não ter influência prática, mas ideológica.

As respostas a nós fornecidas por $60 \%$ das entrevistadas foram variadas e as agrupamos por afinidade. Para $19 \%$ das leitoras, por exemplo, as informações obtidas as capacitam ou as ajudam na socialização. Já para $12 \%$ das entrevistadas, o jornal interfere na formação da própria opinião sobre diversos assuntos.

Cabe lembrar que o jornal leva ao leitor, em suas páginas, a informação que ele interpreta e à qual dá sentido, conforme sua bagagem mental. Sendo assim, a informação veiculada pela mídia é transformada pelos indivíduos que a ela têm acesso, o que os torna elos informacionais. A capacidade de interferir nesta "construção" da informação será maior ou menor, de acordo com suas condições e relações sociais. Dessa forma, as informações, por eles reconfiguradas, circulam retrabalhadas, segundo diversos pontos de vista e objetivos.

\subsection{Temas compartilhados}

Quais temas, então, elas preferem compartilhar? 78 entrevistadas responderam ser política; 36 saúde e bem estar; 30 cultura; 22 temas regionais; 18 todos; 17 economia; entre outros. Temas considerados pelo senso comum como sendo típicos do universo feminino, como moda e filhos, foram citados apenas uma vez cada.

Percebe-se que, em relação a todos os temas citados, é menor o número de leitoras que os compartilham do que o número das que os lêem. Observemos alguns exemplos: 107 disseram ler política, enquanto 78 delas o compartilham; 103 lêem a editoria Gerais e 22 compartilham temas regionais editados em suas páginas; 102 se interessam pela cultura, mas 30 discutem com os outros seu conteúdo; 95 lêem as páginas da editoria Nacional e apenas quatro citaram utilizar o assunto em suas conversas.

\subsection{A mulher "em destaque"}

Foi-lhes perguntado quais cadernos destacam a participação das mulheres na sociedade. Em primeiro, aparece o Feminino \& Masculino, com 73 citações, sendo essa editoria lida por 94 das leitoras. Aliás, em todas as editorias o número de mulheres que as lêem é maior que o número de leitoras que as vêem destacando o gênero feminino. A editoria de Política destaca a mulher na visão de 65 das entrevistadas e é lida por 107; a de Cultura é lida por 102 entrevistadas e destaca o feminino na visão de 51; a Bem Viver, lida por 76, foi citada por 44 entrevistadas. 


\subsection{Imagem}

Pedimos às entrevistadas que nos descrevessem a imagem que, geralmente, o jornal passa da mulher, através de seus textos e fotografias, sem citarem nenhum evento específico ou edição. Essa pergunta também teve respostas variadas, que foram analisadas em categorias por afinidade.

Quanto à imagem transmitida pelos textos, 30 delas não responderam e 13 não souberam fazê-lo. Mais uma vez nos surpreendemos com o alto número de abstenções. Se as entrevistadas buscam informação na leitura de jornais, se elas os lêem na procura de conhecimento que as possibilitem se posicionar tanto em ambientes privados como públicos, como entender o fato de muitas delas não responderem a esta questão? Acreditamos que elas tenham entendido a pergunta e não responderam, principalmente, porque nunca pensaram em fazer essa correlação. 64 entrevistadas acham que o jornal passa uma imagem positiva da mulher; 29 entrevistadas vêem através do jornal uma mulher atuante; dez acreditam que o jornal tanto destaca pontos positivos quanto negativos da mulher; nove acham que o jornal é imparcial, neutro, no tratamento à mulher. Para oito entrevistadas, a imagem da mulher construída pelo jornal é negativa; e seis acham que a mulher sequer tem espaço dentro do jornal.

No que se refere à imagem transmitida pelas fotos, 30 não responderam e 19 não souberam definir. Mais uma vez, o número de entrevistadas que não contribuíram com sua opinião foi expressivo. Entre as que responderam à pergunta, 88 acreditam que as fotografias auxiliam a construir uma imagem positiva da mulher; 20 acham que as fotos tanto mostram pontos negativos quanto positivos; e a imagem é negativa para 11 das entrevistadas.

O que mais chama a atenção nesses resultados é que, proporcionalmente à freqüência das citações, o número de entrevistadas que vêem o jornal retratando a imagem da mulher de forma positiva através dos fotos é maior do que o número das que vêem as editorias destacando a participação feminina na sociedade.

\subsection{Opinião}

Percebemos através das entrevistas que a leitura de jornais contribui de forma significativa para a construção da opinião de $12 \%$ das entrevistadas. Porém, detectamos que a leitora não tem interesse em contribuir com o jornal enviando-Ihe sua própria opinião. São pouquíssimas aquelas que enviam correspondências para o jornal: 94,2\% das entrevistadas nunca o fizeram. 
A justificativa mais utilizada foi a falta de interesse, de motivo, de vontade e de necessidade, totalizando $61 \%$ das respostas. Agrupamos as respostas em uma só porque as próprias entrevistadas as utilizaram em conjunto, como sinônimos ou correspondentes. Em segundo lugar, com $14 \%$, vem a falta de tempo, o que demonstra certo desejo, necessidade, interesse e motivo para fazê-lo. Outras $8 \%$ já deixaram esse desejo mais evidente, mas disseram que sempre há um impedimento como falta de tempo, dificuldades para enviar, entre outros.

Acreditamos haver por parte dos jornais, de uma maneira geral, certa falta de interesse em abordar e interpretar os anseios e as mensagens subliminares contidas nas cartas de seus leitores. Certamente elas não estão sendo devidamente interpretadas pelas empresas como indicadores importantes para o processo de construção da notícia. Na verdade, a maioria dos veículos não tem um setor empenhado em interpretar as "reais" informações contidas nessas correspondências, tendo, normalmente, apenas um profissional que as lê, as recorta e as publica. O conteúdo das cartas fica restrito à editoria de Opinião e aos leitores, seu destinatário final. Ninguém mais dentro do jornal parece se importar com elas.

Interessante observar que 57 entrevistadas disseram ler as páginas de Opinião, editoria em que as cartas são publicadas. Para os jornais, de uma maneira geral, parece não importar a opinião do leitor. Publicar as cartas e "abrir" espaço para a participação tem mais uma função de sondagem mercadológica do que de servir como instrumento para rever a si próprio.

Apesar de, na prática, o espaço de publicação de cartas não acolher debates relevantes e significativos, muito menos servir como efetivo controle da imprensa ${ }^{2}$, seu estudo pode nos dar uma idéia sobre os usos feitos pelo leitor desse tipo de canal de interação. Para Braga (2002), mais que demonstrar a eficácia direta e imediata do controle dos jornais, - estudo das cartas de leitores nos auxilia a perceber as lógicas do processo, "assim como sua potencialidade de fornecer aos usuários (à sociedade, portanto) um instrumento crítico-interpretativo que possa ampliar sua competência de 'leitura', de escolha, de 'edição'" (p.135). Na visão do autor, as cartas funcionam como uma "resposta" do leitor ao jornal. Já para Melo (1994), a carta distancia-se totalmente da temporalidade, não coincidindo com o "momento eclosivo" dos fatos. Porém, resgata o outro lado do fluxo jornalístico: o do receptor, o da coletividade.

Braga (2006) explica que a relação jornal-leitor, estabelecida através das cartas entre produtores e usuários do produto, constrói (ou deveria construir) uma dependência mútua. "Essa relação [...] depende largamente de como cada uma das partes 'constrói' a outra, das

\footnotetext{
${ }^{2}$ Essa foi a conclusão de Braga (2002), a partir de pesquisas realizadas por diversos autores em colunas de correspondências feitas na Inglaterra, desde o século XVIII até 1977 , e de suas próprias pesquisas realizadas em jornais brasileiros.
} 
expectativas e das reivindicações segundo as quais atribui papéis ao interlocutor" (p.290).

O fato de mulheres de todas as faixas etárias lerem jornais nos leva a acreditar que a idade não seja um fator determinante para que elas enviem ou não cartas às redações. Chegamos a essa conclusão porque é semelhante o número de cartas assinadas por mulheres e publicadas nos sete jornais analisados: Estado de Minas, Hoje em Dia, O Tempo (concorrentes locais do EM), O Globo, Estado de São Paulo, Folha de São Paulo e Correio Brasiliense. O Estado de Minas, por ter um alcance local significativo, recebe quase que exclusivamente correspondências de mulheres que residem no Estado. Já a Folha de São Paulo, jornal de maior alcance, distribuído de norte a sul do país, recebe correspondência de leitores e leitoras de todas as cinco regiões brasileiras. Ao confrontarmos a publicação de cartas assinadas por mulheres nesses dois jornais e nos outros cinco, percebemos que o silêncio está longe de ser exclusividade da mineira.

\subsection{Carta de leitores}

Uma das maneiras de se criticar a mídia, e o que parece ser o elemento de maior interatividade nos jornais, citada tanto por Braga (2002) quanto por Mouillaud (2002), são as cartas dos leitores enviadas aos jornais. A carta aparece entre os gêneros jornalísticos opinativos, uma manifestação reivindicatória, cultural ou emocional do leitor. É onde ele fala com o jornal, no jornal e sobre o jornal. Estudá-las nos auxilia a perceber as lógicas do processo de interação entre o leitor e os meios de comunicação de massa.

Acreditávamos que, no caso feminino, a baixa participação nos espaços destinados à interação jornal/leitor e, conseqüentemente, leitor/público, denunciava que falta à mulher a conquista de uma nova relação social, na qual se posicione como sujeito que "fala" e que não se contenta em "ouvir". O "silêncio" decorria, principalmente, do domínio feminino no âmbito do privado, no qual a expressão através da escrita não vai muito além de "receitas e recados" (TEBEROSKY, 1998).

Contabilizamos, então, o número de cartas de leitores recebido pela editoria de Opinião do Estado de Minas, entre 25 de julho a 23 de agosto de 2006. Nesse período, o jornal recebeu 59 cartas femininas e 198 masculinas, o que totaliza 257 cartas. Dessas, 173 foram publicadas: 141 assinadas por homens e 32 por mulheres. Comparando-se o número de cartas enviadas e editadas por sexo, percebe-se que o sexo masculino foi privilegiado: entre as 59 cartas femininas recebidas, 32 delas, ou seja, $54 \%$, foram publicadas. Já entre as 198 enviadas por homens, 141, ou $71 \%$ delas, foram publicadas. Apenas os dados numéricos não são suficientes para concluirmos que a edição da página é tendenciosa, pois o que mais conta, segundo os responsáveis pela leitura e pela publicação das cartas, é o conteúdo e a pertinência do tema abordado. Mas, com certeza, isso nos indica que uma pesquisa mais aprofundada nesse sentido merece ser realizada. 
Percebemos uma baixa representação da opinião feminina também nos concorrentes mineiros do Estado de Minas. O Hoje em dia publicou 89 cartas assinadas por homens e 16 por mulheres, e O Tempo 151 de homens e 42 de mulheres.

A Folha de São Paulo publicou, no período analisado, 204 cartas masculinas e 37 femininas; O Globo 512 cartas de homens e 148 de mulheres; o Estado de São Paulo 261 cartas de homens e 41 de mulheres; e o Correio Brasiliense 135 e 29, respectivamente.

Interessante observar que o espaço para a publicação de artigos de opinião localizado ao lado das cartas dos leitores, destinado a estimular o debate sobre os atuais problemas brasileiros e mundiais, também é "dominado" pelos homens. No Estado de Minas, de 25 de julho a 23 de agosto, foram publicados 89 artigos: 76 assinados por homens e 13 por mulheres. Na Folha de São Paulo, a participação masculina se fez presente em 54 artigos e a feminina em seis. Os artigos de opinião dependem de um convite formal do editor, que normalmente é feito a pessoas de reconhecimento público, sendo raros os enviados (e publicados) espontaneamente pelos leitores comuns. No caso do Estado de Minas, 0 editor de opinião esclareceu que convida poucas mulheres porque são poucas as que se dispõe a escrever. "Quando damos um prazo curto, de um dia para o outro, é mais difícil, ainda, contar com a colaboração feminina", diz.

\subsection{Análise de discurso das capas}

\subsubsection{Fotografias}

Ao colocar todas as capas do Estado de Minas, publicadas entre 25 de julho e 23 de agosto de 2006, alinhadas umas ao lado das outras, percebemos nitidamente uma quantidade superior de homens, sendo que 91 fotografias contendo pessoas, nas quais foi possível identificar os sexos, foram publicadas no período estudado. Desse universo, 60 fotos contêm somente homens, estejam eles sozinhos, em dupla ou em grupo; 11 fotos contêm mulheres sozinhas - três delas referem-se a modelos de alta-costura, quatro reproduzem artistas, duas são 3x4 de candidatas ao Governo de Minas Gerais e duas fotos retratam mulheres comuns. 20 fotos trazem homens e mulheres juntos nos seguintes contextos: grupos de estudantes; manifestantes nas ruas; consumidores; manifestações artísticas; família; procissão religiosa; passeata política; refugiados; transeuntes; grupo de socorro humanitário; ação policial; criadores de cães.

\subsubsection{Manchetes e títulos}

No período analisado, nenhum nome de mulher é citado pelas manchetes principais, enquanto três grandes manchetes trazem nomes de homens públicos. Os títulos, em corpo menor que as manchetes, referemse à situação política, econômica e social que o país atravessa ou servem 
de chamada para shows e eventos culturais. Neles, 67 nomes masculinos aparecem, contra apenas cinco femininos. Interessante notar que, entre os cinco títulos que citam nomes de mulher, três também envolvem um homem.

\section{Conclusões}

Apesar de toda a inegável evolução, a estrutura patriarcal mantémse, permeando as relações sociais. Os problemas enfrentados hoje pelas mulheres têm raízes históricas e sociais profundas, vistos como naturais até por algumas delas e, como tal, difíceis de serem combatidos.

Isso é percebido claramente na sua postura como leitora de um jornal de referência, como visto em relação ao Estado de Minas, através das respostas das que entrevistamos. Elas são quase a metade dos leitores brasileiros de grandes jornais, formando, assim, um enorme público "consumidor" de informação; mas sua relação com a imprensa é marcada pela desigualdade, tanto no que se refere à forma como são retratadas, quanto na maneira como se reportam aos veículos e os pressionam.

O interesse pela leitura da editoria de Política, por exemplo, já havia sido detectado em pesquisas de opinião realizadas pelo Estado de Minas, mas, infelizmente, no senso comum, permanece a impressão de que as mulheres tendem a depreciar e a desprezar o assunto. Isto se deve, acreditamos, à sua ausência nos altos cargos políticos, o que não pode ser interpretado como indiferença e desconhecimento de seus processos. Não podemos ignorar, também, que as mulheres participam ativamente de movimentos sociais e organizações de base na luta pela melhoria da qualidade de vida, principalmente no contexto do ativismo.

O objetivo de leitura mais citado pelas entrevistadas foi a busca de informação (e atualização), que, depois de acessada, é convertida em argumentos com os quais elas se comunicam com o mundo. Estar por dentro do que acontece no Brasil e no mundo parece ser vital para a manutenção da mulher na esfera pública e para o seu reconhecimento, tanto público quanto privado e pessoal.

Porém, o grande número de entrevistadas, 40\%, que optaram por não descrever - ou não souberam responder - de que forma os assuntos lidos no jornal interferem em sua participação na sociedade, nos mostrou certa contradição com o que disseram ser seu principal objetivo de leitura. Vimos que $58 \%$ o fazem à procura de informação e $20 \%$ para se atualizar. Se a comunicação entre os indivíduos é feita através da troca de informações, e se esta informação, a princípio, possibilita aos sujeitos adquirirem consciência de seus direitos e deveres para, a partir daí, tomarem decisões práticas sobre suas vidas, como avaliar as implicações da informação jornalística na vida dessas mulheres?

Seguindo esse mesmo raciocínio, nos deparamos com outras duas perguntas. A primeira buscou saber qual a imagem que o Estado de Minas 
passa das mulheres: $24 \%$ das entrevistadas não descreveram, assim como $26 \%$ não o fizeram em relação à questão que procurou levantar qual a imagem que as fotografias passam do gênero feminino. Poderíamos acrescentar ainda o alto índice de entrevistadas, 43\%, que disseram não ter nenhuma sugestão a dar ao jornal para que ele fique mais interessante para as mulheres. Se elas se posicionaram como sujeitos à procura de informação política e local, além de cultural, para se manterem por dentro do que está acontecendo em suas regiões e no mundo, como entender o fato de que não se interessam ou não se preocupam em avaliar como a imagem social do gênero ao qual "pertencem" é passada ao grande público? Essa falta de sintonia, a nosso ver, deve ser "lida" dentro de um campo mais amplo de avaliações, dentro da própria contradição do papel que se espera da mulher em nossa sociedade e na cultura ocidental.

Por outro lado, parece-nos que a leitora acredita na capacidade e potencialidade da informação jornalística de provocar mudanças na sua vida e interferir na sua participação social, seja no âmbito do público, no meio profissional ou no privado, quando dialoga com os seus ou precisa tomar decisões. Ela lê com o objetivo de se informar; se informa com o objetivo de se comunicar, trocar idéias e construir sentidos para si e para o mundo.

A leitora do Estado de Minas busca a informação e faz deste movimento uma necessidade; mas parece não ter muito interesse em "responder" e interagir com o jornal através de palavras diretas, ou seja, do envio de correspondências aos seus produtores. Questionamos até que ponto ela estaria utilizando as informações, às quais tem acesso via jornal, para renovar e transformar a visão que tem do mundo. Parecenos, pelas respostas dadas às entrevistas e, principalmente, pelas perguntas que muitas optaram por não responder, que as leitoras, mais do que questionar, vêm contribuindo com a manutenção do status quo reservado ao feminino.

Não podemos esquecer que a recepção é uma atividade situada, de contexto estruturado, que depende tanto de relações de poder quanto dos recursos disponíveis ao receptor. Ao analisarmos o contexto sócio-cultural no qual estão inseridos tanto o jornal como suas leitoras, percebemos o quanto este contexto possivelmente tem influenciado a transmissão e a interpretação das informações.

Mas ainda há uma outra questão permeando tudo isso. As entrevistadas dizem ler política com freqüência e acreditam ser essa editoria a que mais destaca a participação feminina na sociedade. Já a editoria de Opinião é um setor do jornal no qual a política encontra um grande espaço de discussão, não apenas com base no factual, mas, também, dentro de um amplo contexto histórico; por isso é opinativo. 0 que colabora para que a mulher marque presença ao ler sobre Política e Opinião e ausência ao não "responder" às suas questões?

Mais uma vez recaímos sobre o senso comum. Acreditamos que a leitora esteja tão "habituada" a ver a mulher subjugada socialmente, o que se reflete nas páginas dos jornais, que acaba por não dedicar tempo e habilidade para refletir sobre esse fenômeno. A cotidiana falta de 
informação sobre a mulher acaba por "anestesiar" a capacidade reflexiva sobre o tema, tanto por parte das mulheres como dos homens, tanto $o(a) s$ que lêem jornais como o(a)s que os editam e os produzem.

Nossa pesquisa não nos permite afirmar que os jornais escrevem e dirigem seus textos aos homens, mas, ao reproduzir a linguagem e deixar escapar por suas palavras preconceitos sobre a mulher, sem dúvida eles escrevem sobre o lugar social que a ela reservam.

O desenvolvimento de competências pelas leitoras exige um estímulo à crítica e à autonomia que, por sua vez, dependem tanto de condições culturais quanto individuais. Porém, não é de se esperar que os grandes jornais modifiquem sua abordagem do mundo e das relações de poder, sua linguagem, que se preocupem em mostrar as conquistas femininas e que incentivem as mulheres a emitirem sua opinião. Afinal, fazem parte da indústria da informação e vivem do comércio de experiências.

As mulheres aparecem pouco no jornal. Isso é fato. E as leitoras percebem o Estado de Minas como um veículo que retrata a imagem feminina de forma positiva, mesmo que, na verdade, reserve-lhe pouco espaço. Podemos analisar essa constatação por diversos ângulos.

O primeiro, que engloba todos os outros, é que a mídia reproduz relações institucionalizadas, legitimadas e, portanto, incorporadas socialmente. Essas relações muitas vezes não são claramente percebidas pelo público, que chega ao ponto de não mais se incomodar com elas. Todos sabem a posição ocupada pela mulher na sociedade, mas poucos vêem motivos para questionar este fato quando reproduzido pela e na mídia.

Outra perspectiva de análise pode ser o reconhecimento dos avanços das mulheres dentro da sociedade. Elas conquistaram novos e muitos papéis, que as fazem lutar por uma melhor posição social. Como as mulheres chegaram, de certa forma, a todos os setores da vida pública, e como a mídia se faz tão presente na sociedade, fica cada vez mais difícil perceber qual informação veio através da imprensa e qual veio a partir da percepção e da leitura pessoal que cada leitor faz do sistema. Muito do que achamos que lemos, na verdade presenciamos; muito do que acreditamos ter presenciado, no fundo lemos ou vimos seus reflexos em algum lugar.

O jornal se funde e se confunde com o viver e vice-versa. É o resultado do que chamamos de fragmentação do mundo, do espaço público e da realidade. O conhecimento e as opiniões são afetados pelo que a pessoa vê, ouve e experimenta; o que possibilita, a partir daí, a tomada de decisões. A mídia funciona como uma espécie de facilitador da relação entre o leitor e o mundo. Dá a "impressão" do leitor de que está inserido num universo maior do que aquele que ocupa geograficamente. Essa percepção se faz importante, visto que procuramos, através de nossa pesquisa, entender o processo pelo qual informações veiculadas nos grandes jornais afetam os parâmetros utilizados pelas mulheres, tanto para compreender quanto para participar da realidade política, econômica, cultural e social. 
Não podemos deslocar e descontextualizar os indivíduos para fora de suas redes sociais, assim como a informação produzida por eles. No caso das mulheres, elas não devem ser vistas fora da estrutura patriarcal e das desigualdades que as relações de gênero estabelecem. Já que essas forças sociais moldam o desenvolvimento de redes de informação, talvez falte a elas, para participar da construção da notícia e não se contentar apenas em buscar a informação pronta, muito mais do que disposição para atender aos apelos do editor. Para reestruturar este status quo, falta-lhes, principalmente, procurar entender mais sobre os meandros que envolvem a organização social, assim como a informação produzida e disseminada; o que não isenta o jornal da responsabilidade de incluí-las como co-produtoras.

Incluí-las vai além de contratar jornalistas mulheres. Elas também escrevem no masculino, porque essa sempre foi a linguagem do mundo. Incluir a mulher em suas páginas é perceber que elas têm contribuído para a construção da história e para além do crescimento do mercado global de consumo. Por mais que os mercados da estética e da beleza prosperem, a mulher não olha só para eles. Estes já as conquistaram, aproveitando-se dos estereótipos que há séculos definem o feminino.

O fato é que, atualmente, num momento em que elas são quase a metade dos leitores de jornais impressos no Brasil, tanto o imaginário social como os empresários da mídia ainda consideram as mulheres como se buscassem suprir principalmente suas necessidades de subalternas; como seres sem opinião ou de opinião sem muito interesse social. Querendo ou não, as empresas jornalísticas dependem muito da leitura delas para se manterem como estão, mas não demonstram interesse em conhecer $e$ atender aos reais objetivos que as levam a buscar a informação em suas páginas. As pesquisas de opinião geralmente não ouvem um número igual de leitores e leitoras, como se assim não se dividisse seu público ${ }^{3}$. As empresas ainda não partem do pressuposto de que a mulher vai muito além da emoção, do choro, da compulsão ou da posição de vítima de um sistema, que ela, por razões próprias, também ajuda a construir.

\section{Referências}

BARRETO, A. A. Transferência da informação para o conhecimento. In: AQUINO, M. A. (Org.). O campo da ciência da Informação: gênese, conexões e especificidades. João Pessoa: Ed. Universitária, 2002.

BRAGA, J. L. O sistema social crítico interpretativo. In: PRADO, J. L. A. (Org.). Crítica das práticas midiáticas. São Paulo: Hacker Editores, 2002.

DUMONT, L. M. M.. O imaginário feminino e a opção pela leitura de romances em série. 1998. 257f. Tese (Doutorado em Ciência da Informação) - Escola de Comunicação, Universidade Federal do Rio de

\footnotetext{
3 A pesquisa Índice de Satisfação do Assinante (2006), aplicada pelo jornal Estado de Minas, entrevistou 450 leitores, sendo 278 homens e 172 mulheres.
} 
Janeiro e Instituto Brasileiro de Informação em Ciência e Tecnologia, Rio de Janeiro, 1998.

ESCARPIT, R. Sociologie de la littérature. Paris: Presses Universitaires de France, 1958 apud DUMONT, L. M. M.. O imaginário feminino e a opção pela leitura de romances em série. 1998. 257f. Tese (Doutorado em Ciência da Informação) - Escola de Comunicação, Universidade Federal do Rio de Janeiro e Instituto Brasileiro de Informação em Ciência e Tecnologia, Rio de Janeiro, 1998.

ESPÍRITO SANTO, P. Leitura e interatividade feminina nos jornais impressos: a postura da leitora do Estado de Minas. 2007. 330f. Dissertação (Mestrado em Ciência da Informação) - Escola de Ciência da Informação, Universidade Federal de Minas Gerais, Belo Horizonte, 2007.

FIORIN, J. L. Linguagem e ideologia. São Paulo: Ática, 2006.

ÍNDICE de satisfação do assinante - ISA - Estado de Minas. Belo Horizonte: 2006. [não publicado].

IPSOS MARPLAN. XLVIII estudos Marplan consolidado - grande BH. Belo Horizonte: Ipsos Marplan, 2006. Disponível em: <http://www.ipsosmarplan.com.br>. Acesso em: 30 jun. 2006. [Acesso restrito aos associados Ipsos Marplan].

LE COADIC, Y. A ciência da informação. Brasília: Briquet de Lemos, 1996.

MELO, J. M. A opinião no jornalismo brasileiro. Petrópolis-RJ: Vozes, 1994. MOUILLAUD, M. O nome do jornal. In: PORTO, S. D. (Org.). O jornal: da forma ao sentido. Brasília: Universidade de Brasília, 2002.

TEBEROSKY, A. O conhecimento cotidiano, escolar e científico no domínio da linguagem escrita. In: RODRIGO, M. J.; ARNAY, J. (Orgs.). Conhecimento cotidiano, escolar e científico: representação e mudança. São Paulo: Ática, 1998. v. 2.

THOMPSON, J. B. A mídia e a modernidade. Petrópolis/RJ: Vozes, 1999. 